Pamiętnik Literacki 2018, 3, s. 83-91

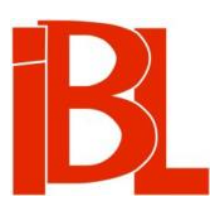

\title{
Skamander i awangarda na ubitej ziemi. $O$ sporze Karola Wiktora Zawodzińskiego i Józefa Czechowicza
}

Marcin Całbecki 
DOI: $10.18318 / \mathrm{pl} .2018 .3 .6$

MARCIN CAŁBECKI Uniwersytet Gdański

\section{SKAMANDER I AWANGARDA NA UBITEJ ZIEMI O SPORZE KAROLA WIKTORA ZAWODZIŃSKIEGO I JÓZEFA CZECHOWICZA}

Janusz Sławiński i Michał Głowiński w swym erudycyjnym wstępie do antologii Poezja polska okresu międzywojennego walczą ze stereotypem, ich zdaniem, fałszującym wizerunek literatury Dwudziestolecia, jakoby ów okres upłynął pod znakiem konfliktu środowisk awangardy ze skamandrytami: „Wszystko razem musi skłaniać do odrzucenia wygodnej skądinąd dychotomii Skamander-awangarda jako zasady porządkującej obraz poezji Dwudziestolecia”' . Autorzy skupili się przede wszystkim na analizie poetyk reprezentantów obu pozornie spierających się ugrupowań i dowodzą, iż nie sposób jednoznacznie przeciwstawić dziś poetów Skamandra i awangardzistów. Niewątpliwie zgłębienie tekstów programowych, założeń estetycznych pozwala na wyciągnięcie podobnych wniosków. Myślę jednak, że można pozwolić sobie na ukazanie relacji Skamander-awangarda $\mathrm{w}$ formie konfliktu, jeśli weźmie się pod uwagę nie merytoryczną treść ich wystąpień, lecz osobiste sądy na temat adwersarzy.

Do takich wniosków skłania chociażby wnikliwa lektura korespondencji Józefa Czechowicza, który wszakże w swej niechęci do środowiska skamandrytów miał poprzedników, gdyż awangarda krakowska także nie darzyła życzliwością warszawskich poetów. Przykładem może być chociażby Julian Przyboś atakujący w Chamułach poezji z 1926 roku m.in. Józefa Wittlina związanego wtedy ze Skamandrem. Jednak to, co zapoczattkowali zwrotniczanie, znalazło swoją kontynuacje wśród przedstawicieli drugiej odsłony ruchu awangardowego już w latach trzydziestych. Wiele wypowiedzi i przedsięwzięć Czechowicza świadczy, że z niechęcią odnosił się on do reprezentantów czasopism redagowanych przez Mieczysława Grydzewskiego.

Czechowicz zorganizował 11 III 1934 w stolicy wieczór poetycki awangardowych literatów nazwany za pomocą metafory militarnej - najazdem awangardy na Warszawę. Owo określenie może wydać się tylko żartem, po przestudiowaniu osobistych wypowiedzi Czechowicza na temat skamandrytów i „Wiadomości Literackich” należałoby jednak przyjąc, że ta pełna wrogości nomenklatura trafnie ukazuje intencje autora ballady z tamtej strony. W liście do Kazimierza Miernowskiego poeta mówi o Kazimierzu Wierzyńskim i Antonim Słonimskim: „dwaj moi osobiści i lite-

1 M. Głowińs ki, J. Sła wińs ki, wstęp w zb.: Poezja polska okresu międzywojennego. Antologia. Wybór ... Przypisy J. Stra de cki. Wyd. 2, przejrz. Wrocław 1997, s. XIX. BN I 253. 
raccy wrogowie” , a w korespondencji do Stanisława Czernika nazywa „ponurym” reaktywowane czasopismo „Skamander”3.

Zatem jeśli istniał spór Skamander-awangarda, to miał on wymiar także prywatnych animozji, te zaś przyniosły istotne konsekwencje związane z życiem literackim. Otóż gra toczyła się w zasadzie o to, kto uprawia prawdziwą literaturę. Nie watpię, że na linii Czechowicz (a pewnie i szerzej: awangarda) - skamandryci szczególnie ci pierwsi życzyliby sobie zamilknięcia tych drugich. Tak więc ów antagonizm daje się jednak zaobserwować w świadomości twórców i odbiorców sztuki w Dwudziestoleciu, a pewna jego odsłona z 1935 roku pokazuje w sposób sugestywny, jak bardzo zamiarem każdej ze stron była potrzeba odebrania głosu przeciwnikowi. W walce o zamilknięcie antagonisty sieggano po wszelkie środki, nie unikano zachowań moralnie nagannych, byle tylko doprowadzić do wykluczenia dokonań rywala ze świadomości odbiorców sztuki. W numerze 4/5 „Okolicy Poetów” z roku 1935 opublikowany został artykuł Czechowicza, który stanowił odpowiedź na ankietę owego czasopisma dotycząca problemu zadań krytyki poetyckiej. Pytania w tej materii zadano ówczesnym poetom, a jednym $z$ nich był właśnie lublinianin. Autor ballady z tamtej strony w sposób oczywisty wymierzył swój tekst w związane ze Skamandrem środowisko „Wiadomości Literackich”, w szczególności zaś w głównego krytyka poezji tego periodyku - Karola Wiktora Zawodzińskiego ${ }^{4}$. Choć w całym artykule jego nazwisko nie było wzmiankowane, wszakże aluzje poczynione przez awangardowego poetę były na tyle wyraźne, że $z$ łatwością można rozpoznać w oskarżanym krytyku właśnie postać Zawodzińskiego. Czytamy tam:

Krytykę polską oskarżam, oskarżam, oskarżam...

Od krytyków należy wymagać bezstronności, odczuwania poezji (tego chyba brak im najwięcej), wreszcie szerokiego światopoglądu filozoficznego, opartego na studiach, nie zaś na poobiedniej lekturze popularyzatorskiej w rodzaju przemiłego skądinąd J. Jeansa. [...] Żądamy także uczciwości handlowej - jeżeli entuzjastyczna recenzja $z$ tomu, popełnionego przez ważnego współpracownika jakiegoś tygodnika literackiego, jest w następstwie zapłacona posada stałego recenzenta $\mathrm{w}$ tymże tygodniku, to dlaczego o tym ma wiedzieć tylko 10 osób? Interes jest interesem. Kto będzie chciał czytać interesowne

2 J. Cze chowicz, list do K. Miernowskiego, z 17 II 1939. W: Listy. Zebrał, oprac. T. Kła k. Lublin 1977, s. 425.

3 J. C z e chowi c z, list do S. Czernika, z 6 X 1935. W: jw., s. 308.

4 K. W. Zawodziński to krytyk literacki, który odgrywał bardzo ważną rolę w środowisku nie tylko Skamandra, człowiek ten był też swego rodzaju instytucją w życiu literackim Dwudziestolecia. Dziś wydaje się zapomniany, choć jego pracy krytycznej poświęcono po wojnie monografię (zob. J. Z. Bi a ł e k, Poglady krytycznoliterackie Karola Wiktora Zawodzińskiego. Wrocław 1969), a jeszcze w 1989 roku A. Z. Makowi e cki wydał i opatrzył wstępem wybór jego pism polemicznych (K. W. Zaw odziński, Pegaz to nie samochód bezkołowy. Szkice krytyczne. Warszawa 1989). Wzmiankuje o nim także Literatura polska. Przewodnik encyklopedyczny (T. 2. Warszawa 1985, s. 677), gdzie w haśle J. W o j n o w s k i e g o dotyczącym tego krytyka in extenso możemy przeczytać: „Zawodziński Karol Wiktor, ur. 1 VI 1890 w Warszawie, zm. 14 XII 1949 w Toruniu, krytyk lit., historyk literatury, wersolog. W 1908-13 studiował filologie rom. na uniw. w Petersburgu, od 1914 w Legionach Pol., 1918-32 służył w WP (w stopniu rotmistrza). [...] bliskie związki łączyły go z grupa [...] Skamandra i jej miesięcznikiem. W 1938 otrzymał Złoty Wawrzyn PAL. Od 1946 prof. UMK, wykładał historię literatur słowiańskich. Jeden z najwybitniejszych znawców poezji w 20-leciu międzywojennym, obdarzony wyrobionym smakiem i kultura artyst., był krytykiem o upodobaniach klas., wartościującym utwór poet. wedle tradycyjnych kryteriów harmonii i umiaru, regularnej wersyfikacji i rytmiki, przeciwstawiał się natomiast dążeniom poet. Awangardy". 
recenzje, weźmie do ręki produkty owego recenzenta. A kto będzie chciał czytać recenzje interesujące, weźmie się do lektury innych pism literackich. To takie proste! ${ }^{5}$

Nietrudno zauważyć, że Czechowicz dążył do wykluczenia „Wiadomości Literackich" i tamtejszego działu krytyki $z$ aktualnego życia literackiego. Środki perswazji, którymi się poeta posłużył, ewidentnie miały na celu zdyskredytowanie wiarygodności Zawodzińskiego i odebranie mu prawa głosu w sporach literackich Dwudziestolecia. Posądzenie go zaś o korzyści materialne płynące $z$ faktu tworzenia dobrych bądź złych recenzji i postawienie w dwuznacznym świetle działu krytyki „Wiadomości Literackich” wydaje się brutalną strategią awangardy wymierzoną w dobrze sytuowane środowisko artystyczne skupione wokół pism redaktora Grydzewskiego. Narracja spreparowana przez Czechowicza była dość czytelna: my stanowimy prawdziwą literaturę, podejmujemy ważne dla życia społecznego tematy i interesują nas autentyczne problemy estetyczne, wy zaś jesteście wyłącznie komercyjnym przedsięwzięciem, jesteście zwykłymi groszorobami, dlatego lepiej by się stało dla literatury, gdybyście zamilkli.

Narracja stworzona przez Czechowicza, oczywiście fałszywa i skamandrytów krzywdząca, brzmi jak memento dla dzisiejszych dylematów związanych z wprowadzeniem dóbr kultury w sferę merkantylną. Współczesne życie literackie także zdaje się ulegać komercjalizacji. Marketing i promocja jakby wypierają merytoryczne i bezinteresowne spory krytyki wokół znaczenia wykreowanego dzieła. System sowicie opłacanych nagród jest podstawową formą tworzenia kanonu wartościowych tekstów. Wszystkie te mechanizmy znano już w Dwudziestoleciu, stanowisko Czechowicza zaś stanowi wymowne świadectwo świadomości konfliktu między bezinteresownością dzieła sztuki i piękna a mechanizmami kapitalistycznej gospodarki, do której przynależą też zasoby dóbr kultury. Spór o status literatury w kontekście uwarunkowań ekonomicznych, dylemat, czy jest ona przedsięwzięciem niezależnym od porządku merkantylnego, czy raczej należałoby założyć, że pisanie i publikowanie to taka sama produkcja, jak wytwarzanie innych dóbr, został rozwiązany poprzez wyznaczenie granicy między sztuką uznawaną za komercyjną a tą, która deklaruje swą niezależność wobec uwarunkowań ekonomicznych. Zbudowanie schematu dwóch literatur, dwóch wizji funkcjonowania sztuki potwierdza tezę o dwutorowości sztuki w okresie modernizmu. Odkrył tę podwójność Pierre Bourdieu, a w swym studium Reguły sztuki. Geneza i struktura pola literackiego zaprezentował właśnie starcie dwu pól literackich w dobie nowoczesności analogiczne do zakreślonego przez Czechowicza:

Te pola są miejscem antagonistycznej koegzystencji dwóch sposobów produkcji oraz obiegu dóbr, posłusznych przeciwstawnym logikom. Na jednym biegunie „antyekonomiczna” ekonomia sztuki czystej, oparta na uznaniu należnym walorom bezinteresowności oraz na zaprzeczeniu „ekonomii” (opartej na „Zysku”) oraz korzyści „ekonomicznych” (krótkoterminowych), uprzywilejowuje produkcję oraz jej specyficzne wymogi, wyrastające $z$ historii autonomicznej. [...] Na drugim biegunie sytuuje się logika „ekonomiczna” przemysłu artystycznego oraz literackiego, która czyniąc $z$ handlu dobrami symbolicznymi taki sam handel, jak każdy inny, przyznaje priorytet rozpowszechnianiu, bezpośredniemu, chwi-

5 J. Czechowicz, Odpowiedź na ankietę. W: Szkice literackie. Oprac. T. Kłak. Lublin 2011, s. 71-72. Pisma zebrane. T. 5. 
lowemu sukcesowi, mierzonemu na przykład wielkością nakładu i poprzestaje na dostosowywaniu się do uprzednich wymagań klienteli $[\ldots]^{6}$.

Strategia perswazyjna Czechowicza w jego artykule dąży do takiego antagonistycznego ujęcia wzajemnych oddziaływań pól literackich oraz przypisuje awangardzie bezinteresowność i autentyczność artystycznego wyrazu, a swoim przeciwnikom z „Wiadomości Literackich” przyznaje stanowisko związane z podporządkowaniem procesu twórczego prawom ekonomii i rynku, i to w każdym możliwym wymiarze. Zarzut komercjalizacji jest kluczowy w tym, aby odebrać owemu środowisku prawo głosu. Skazanie na banicję milczenia ma zatem nastąić, żeby uchowała się sztuka „czysta”, prawdziwa, niezależna od uwarunkowań ekonomicznych. Logika tego wywodu potwierdza ustalenia Bourdieu o starciu dwóch różnych sposobów produkcji na rynku dóbr symbolicznych, gdzie produkcja awangardowa stosuje swoista przemoc symboliczną, mająca na celu pozbawienie konkurenta wszelkich praw i wiarygodności. Konkurent zaś, czyli sztuka skrojona na mieszczańskie gusty, dysponuje zarazem całą maszyneria rynku wydawniczego i de facto kreuje gusty odbiorców w stopniu znacznie większym niż niszowa twórczość skierowana na skrajną oryginalność.

Sztuka komercyjna lub za taką uchodząca (bo nie inaczej traktowali awangardziści środowisko „Wiadomości Literackich”) dysponuje jednak potężną bronią, która jest zgodność systemu wartości, jaki promuje, $z$ dominującym $w$ danym społeczeństwie zespołem odczuć moralnych. Nie prowokując, ani nie penetrując odmienności sztuka taka potwierdza tylko utarte już systemy wartościowania i tym sposobem znajduje akceptację wśród odbiorców. Mając świadomość przewagi i symbolicznej mocy takiej sztuki, osobiście zaatakowany Zawodziński przygotował odpowiedź, w której problem milczenia jako wyniku skutecznej presji społecznej znalazł swój ciagg dalszy. Niedługo po opublikowaniu w „Okolicy Poetów” Czechowiczowskiego odzewu na ankietę tego czasopisma, przedstawił on odpowiedź zatytułowaną Genus irritabile vatum. Ukazała się ona w „Wiadomościach Literackich”, w numerze feralnego dla Czechowicza i Zawodzińskiego roku 1935.

Strategia przyjęta przez Zawodzińskiego polegała na rozszerzeniu zakresu argumentacji o najbardziej drażliwe dla życia społecznego kwestie. Aby zmusić antagonistę do milczenia, posunął się on do oskarżenia Czechowicza o niemoralność. Oto fragmenty ze wspomnianego artykułu z „Wiadomości Literackich”, które ową polemikę zmieniły w chęć zdezawuowania adwersarza w sposób wyjątkowo bezwzględny:

W tym tedy piśmie [tj. w „Okolicy Poetów”], po rozmaitych przyczepkach i wycieczkach polemicznych oraz drobnych insynuacjach, które można było zbyć lekceważącym milczeniem, zjawiła się kalumnia grubszego kalibru. Wypłynęła ona spod pióra p. Józefa Czechowicza, poety skądinąd nie pozbawionego zdolności, zjawiając się jakby na potwierdzenie tezy, bronionej przeze mnie w zeszłorocznym „Zecie”, że talent artystyczny wcale jeszcze nie gwarantuje moralnej wartości człowieka ${ }^{7}$.

W dalszej części tego artykułu padają zaś słowa, których przesłanie jednoznacz-

$6 \quad$ P. Bo u r d i e u, Reguty sztuki. Geneza i struktura pola literackiego. Przeł. A. Zaw a d z ki. Kraków 2007, s. 219-220.

7 K. W. Zaw o d ziń s ki, Genus irritabile vatum. „Wiadomości Literackie” 1935, nr 50, z 15 XII, s. 2. 
nie zmierza do pogrążenia przeciwnika i uczynienia zeń obiektu potępienia, a zatem - naznaczenia go w porządku kultury statusem kozła ofiarnego:

Tak jak najłatwiej podnosi rękę na człowieka pijany cham, dla którego policzek mierzy się tylko siłą zadającej go pięści, tak człowiek bez czci, bez instynktu moralnego najłatwiej rani cudzy honor, imputując niskie pobudki czynom innego ${ }^{8}$.

Przywołanie kategorii etycznej i argumenty mówiące, że „talent artystyczny nie gwarantuje moralnej wartości człowieka”, odsądzanie Czechowicza od czci i instynktu moralnego to strategia bezwzględna, gdyż dotyka ona lęku łatwego do sprowokowania u każdej zbiorowości. Niemal wszystkie wspólnoty zazwyczaj reagują wyjątkowo neurotycznie, jeśli w argumentacji pojawiają się sugestie co do łamania praw etycznych, regulujących życie. Skądinąd świetnie ten rodzaj nerwicy społecznej opisał Thomas Mann w opowiadaniu Mario i czarodziej, mówiącym o źródłach włoskiego faszyzmu. Zawodziński wykorzystał zatem dość perfidnie jedna $z$ najbardziej skutecznych metod odbierania adwersarzowi autorytetu, skazywania takiej osoby na publiczne potępienie. $Z$ punktu widzenia życia literackiego był to w zasadzie cios podważający wiarygodność Czechowicza. Bez wątpienia możliwość wykorzystania przez krytyka takiej argumentacji wpisuje się w przekonanie, że egzystencją zbiorowości kierują reguły oparte na zasadach dominacji i przemocy, że w ramach relacji społecznych główną rolę odgrywa przemoc symboliczna, a zabiegi retoryczne stosowane we wspólnocie, odwołujące się do argumentów moralności, na celu mają uruchomienie mechanizmów wykluczenia. Skutkować zaś to powinno zamilknięciem adwersarza, odebraniem mu głosu.

Spór o prawo do wyrażania wiarygodnych sądów na temat literatury - który toczył się w 1935 roku na łamach czasopism kulturalnych i który zamienił się w próbę przekonania publiczności, iż przeciwnik nie ma prawa wypowiadać się w kwestiach literatury oraz musi pogodzić się z własnym milczeniem, gdyż jest niegodny, aby zajmować publiczne stanowisko w jakiejkolwiek sprawie - zapamiętał Czesław Miłosz. Następująco przedstawiał on sytuację Czechowicza w związku Z atakiem Zawodzińskiego:

zwłaszcza nienawiścią pałał do niego [tj. Czechowicza] w tym kręgu [tj. „Wiadomości Literackich”] K. W. Zawodziński. Ta figura była interesująca. Oficer kawalerii, dosłownie opętany miłością do poezji, stał się naczelnym krytykiem poetyckim i wkład jego w badania nad wierszem polskim mógłby być poważny, gdyby nie liczne aberracje ${ }^{9}$.

Świetnie został ujęty przez noblistę społeczny mechanizm wykluczenia, a postawę krytyka, o którym mowa, wytłumaczył Miłosz swoistym pieniactwem, co ukazują fikcyjne cytaty odnoszące się do pospolitych sytuacji, znakomicie obrazujace niską motywację Zawodzińskiego, który „uderzył w Czechowicza w imię oburzonej moralności ("Pan nie wiesz, z kim pan masz do czynienia", "Ja pana zniszczę")"10.

W rzeczy samej, sytuacja, w jakiej znalazł się Czechowicz po artykule zamieszczonym w numerze 50 „Wiadomości Literackich”, daje się rozpoznać jako proces postępującego wykluczenia społecznego. U Miłosza czytamy: „Otóż głównie namięt-

Ibidem.

Cz. Miło s z, Czechowicz - to jest o poezji między wojnami. W: Kontynenty. Kraków 1999, s. 336.

Ibidem, s. 337. 
ności Zawodzińskiego przyczyniły się do stracenia przez Czechowicza posady $\mathrm{w}$ "Płomyczku" "11. Zatem spór, który wydawał się tylko polemiką na polu literatury i którego źródła wypływały z odmiennych wizji na temat poezji środowiska Skamandra i awangardy, zamienił się w brutalną próbę wykluczenia jednej ze stron z życia nie tylko literackiego, lecz także społecznego. Miłosz, przed wojną, oczywiście, będący bliżej awangardy, a ściślej - jej drugiej odsłony, przedstawia ów antagonizm z perspektywy Czechowicza, z którym razem pracował w Polskim Radiu w Warszawie. Ale nie ulega wątpliwości, że konsekwencje, jakie spotkały autora ballady $z$ tamtej strony, były dużo drastyczniejsze. Sytuacja Czechowicza stała się bowiem krytyczna, co potwierdzają następujące słowa: „Powtarzam tylko to, co opowiadał mi Czechowicz, który "Wiadomości» i Zawodzińskiego czynił odpowiedzialnymi za utratę domu na Powiślu i nędzę, w jaką popadł"12.

Widzimy zatem, że sprawa zrobiła się bardzo poważna. Czas zatem teraz sprecyzować powody, dla jakich Zawodziński odwołał się do tak niebezpiecznej argumentacji odnoszącej się do kwestii nie tyle obrażonej moralności, ile jej braku. $Z$ dzisiejszej perspektywy stają się owe zarzuty swoistym memento i warto je poznać także w związku ze współczesnym sporem o kształt społeczeństwa.

Zarzuty o niemoralność postawione przez Zawodzińskiego dotyczyły bowiem homoseksualizmu autora ballady z tamtej strony i krytyk „Wiadomości Literackich” w sposób niezwykle brutalny upokorzył Czechowicza, piętnując go z powodu orientacji seksualnej. Kiedy w związku ze sporem lubelski poeta bliski był zorganizowania pojedynku honorowego, zgodnego z kodeksem Władysława Boziewicza, spadł na niego cios, który Czechowicz skwitował pisząc 11 XII 1935 następujące słowa do Kazimierza Andrzeja Jaworskiego: „Pan Zawodziński stara się pogrzebać mnie cywilnie w opinii publicznej" ${ }^{13}$. Owo napiętnowanie i upokorzenie, czyli owa śmierć cywilna, doszły do głosu w liście otwartym, który rotmistrz wysłał do „Kameny”. Czytamy w nim:

Decyzja p. Czechowicza niepojedynkowania się ze mną b. upraszcza sprawę, gdyż z jednej strony mundur, który noszę, obowiązuje mnie do dania satysfakcji honorowej, z drugiej strony, osoba mego przeciwnika wywołałaby wielkie wątpliwości co do tzw. „Satisfactiontätigkeit”"14.

Tym sposobem Zawodziński wykorzystał dość perfidnie pełna przemocy retorykę, która w swej argumentacji odnosiła się do niebezpiecznych stereotypów i klisz żywych jeszcze w Dwudziestoleciu. W rezultacie Czechowiczowi w zasadzie odebrano godność. Atak Zawodzińskiego miał na celu właśnie pozbawienie go jakichkolwiek praw i rotmistrz dopiął swego.

Jest wszakże rzeczą dość irytująca, że w relacji z tego zdarzenia pióra Wacława Gralewskiego, który pewne sprawy jednak myli, do głosu dochodzi oburzająca dezynwoltura. Ten dawny przyjaciel poety miał bowiem przede wszystkim ubaw z udanej, jego zdaniem, riposty Zawodzińskiego. Autor Stalowej tęczy wspomina:

$11 \quad$ Ibidem, s. 336-337.

12 Ibidem, s. 337.

13 Cyt. za: K. A. J aw orski, Józef Czechowicz. W zb.: Spotkania z Czechowiczem. Wspomnienia i szkice. Oprac. S. Polla k. Lublin 1971, s. 123. 
W swym głównym polemicznym artykule Genus irritabile votum oświadczył [Zawodziński] m.in., że nie kieruje sprawy na drogę honorową, ani w razie czego satysfakcji honorowej dać nie może ze względu na niezdolność Czechowicza do jej udzielenia czy też wzięcia. Było to na owe czasy mocne postawienie sprawy. Kodeksy i tradycja honorowa nie przewidywały dawania satysfakcji honorowej kobietom, duchownym, osobom pozbawionym czci przez sądy i... homoerotom ${ }^{15}$.

Nie dość, że Gralewski myli się, bo to nie w artykule z „Wiadomości Literackich”, lecz w otwartym liście do „Kameny” Zawodziński ten problem podją, to jeszcze autor Stalowej tęczy prezentuje cały problem w stylu, który nie wystawia najlepszego świadectwa jego wrażliwości. Mamy wszak w liście Zawodzińskiego próbę publicznego napiętnowania i wyszydzenia człowieka ze względu na jego orientację seksualną, a Gralewski traktuje to jako dobry dowcip, stwierdzenie zaś, że „Zawodziński był doświadczonym polemistą i polemikę zakończył nokautem" ${ }^{16}$, stanowi wyraz całkowitej ignorancji w kwestiach społecznych.

Tę głośną sprawę przypomniałem właśnie $z$ tego powodu, że milczenie to nie jedynie uduchowiona forma kontaktu $\mathrm{z}$ absolutem czy hermeneutyczny rewers pełnego zrozumienia, ale też efekt działania sił społecznych, skutek funkcjonowania symbolicznej przemocy zadowolonego z siebie społeczeństwa, które dysponuje rozbudowanymi środkami, aby osobę do milczenia zmusić i tym sposobem ją napiętnować i upokorzyć. Jeszcze niedawno wszelkich odmieńców skazywano na milczenie. Milczenie nie tylko jest narzędziem wzruszenia, lecz może stanowić także formę kary, jaką społeczeństwo wymierza inności. Milczenie może być upiorne - to rodzaj krzyku bezsilnej jednostki, napiętnowanej przez uprzedzenia wspólnotowe. Czechowicz w liście do Czernika sytuację swoją opisał następująco:

Jeśli chodzi o moje sprawy, moje przykrości, nie potrzebuję chyba zaznaczać, że nie chodzi o żadne kwestie służbowe czy finansowe. Oskarżono mnie, gdzie należy, o życie niemoralne, orgie itp., popierając cytatami z poematu hildur baldur $i$ czas! Czy to nie cudowny pomysł? Jaka szkoda, że na podstawie wiersza o bohaterstwie w łodzi podwodnej nie przedstawiono mnie do krzyża Virtuti Militari ${ }^{17}$.

Jeśli zaś istotnie przesłanki do oskarżenia o niemoralność wywiedziono z poematu, to potwierdza to przypuszczenie o szczególnej sile tzw. społecznej przemocy symbolicznej, a dzieło sztuki na stałe uwikłane zostaje w zespół interakcji socjalnych i fikcja jest przekonanie, że utwór literacki może funkcjonować poza porządkiem wspólnotowym. Zbiorowość bowiem wyznacza horyzont odbioru i weryfikuje dzieło pod względem respektowania ustalonego systemu wyznawanych wartości. To społeczeństwo i jego represyjne uwarunkowania decydują, kto może być poetą, i przyznają prawo głosu lub skazują kogoś na milczenie. Ofiara owej niezwykle drastycznej reguły padł Czechowicz. Ośmielił się napisać utwór o miłości homoseksualnej. W efekcie został oskarżony o niemoralność i był to cios, który przyniósł ostatecznie decyzję o dobrowolnym wycofaniu się pisarza z życia literackiego. Tym samym figura milczenia pojawia się $\mathrm{w}$ owym sporze $\mathrm{z}$ lat trzydziestych jako wyraz ulegania presjom wartości mieszczańskich, stanowi osobliwy krzyk rozpaczy jednostki doświadczającej upokorzenia i napiętnowania. W takich słowach poeta przedstawił swoje postanowienie w liście otwartym do „Kameny” 11 XII 1935:

17 Cyt. za: S. Czernik, Czechowicz. W zb.: Spotkania z Czechowiczem, s. 354-355. 
Umrę cywilnie. Wycofam się z życia literackiego. Zastosuję bierny opór. Nie będę publikował swoich prac poetyckich ani też prozatorskich, ani artykułów, ani żadnej rzeczy, która moja jest.

Rad jestem, że możni naszego świata literackiego, serdeczni przyjaciele pana Zawodzińskiego, oszczędzą sobie fatygi i nie będą musieli mnie „tępić i likwidować”. Przez autolikwidację rozpocznę także nową erę w stosunkach literackich w Polsce, bo o ile mi wiadomo, nie było jeszcze u nas poety, by zastosował bierny opór... ${ }^{18}$

Doszliśmy zatem do istoty społecznego wymiaru i statusu milczenia. Jest ono przede wszystkim forma protestu wobec niesprawiedliwości, protestu dramatycznego, gdyż milczenie czyni $z$ jednostki ofiarę represywnego systemu wartości, który dysponuje siłą odbierania głosu. Czechowicz decyduje się sam na zamilknięcie i traktuje to jako sposób zbuntowania się przeciwko złu. Skoro adwersarz poety pisał o „tępieniu i likwidowaniu” przeciwnika, to takie metody uwidaczniają niezwykle wymownie, że oryginalna twórczość literacka to zajęcie niezwykle niebezpieczne. Wynika to $\mathrm{z}$ faktu, iż każdy tekst nie tylko wchodzi $\mathrm{w}$ dialog $\mathrm{z}$ dziełami poprzedników, lecz także musi się zmierzyć $z$ presją systemu społecznego, dla którego respektowanie przyjętych wartości odgrywa znacznie większą rolę niż oryginalność wypowiedzi. Czechowicz przekonał się w sposób niezwykle bolesny, że - jak ujał to Harold Bloom - „bez względu na to, jak bardzo solipsystyczni są najsilniejsi z poetów, musimy przestać myśleć o poecie jako o autonomicznym ego"19. Nie tylko wielki poprzednik z Bloomowskiej teorii poezji, lecz również społeczeństwo stanowi czynnik mogący odebrać poecie głos.

Czechowicz postanowił zamilknąć. Uznał, że przygotowany właśnie tomik będzie jego ostatnim i w tych słowach, w liście do Jaworskiego zadeklarował swoje wycofanie się z życia literackiego:

Tom mój, ostatni w kolejności i już w ogóle ostatni, ukaże się w ciągu tego tygodnia. Jest już po wszystkich korektach i podpisałem go do druku. [...] Nazywa się nic więcej i wychodzi u Hoesicka ${ }^{20}$.

Decyzja o zamilknięciu w związku z atakami na niemoralność szczęśliwie została zmieniona i w 1939 roku poeta wydał nutę człowiecza. Wtedy właśnie zadeklarował poczucie głębokiej „wspólnoty z ludźmi, [...] do współczucia z nimi ${ }^{21}$ ” i zerwał z solipsystycznym fantazjotwórstwem. Niewykluczone, że ten przełom stanowił echo konfliktu, który został opisany w niniejszym artykule. To nuta człowiecza była dla Czechowicza tomem przełomowym, rozpoczynajacym nowy etap jego twórczości. Niestety, czytelnicy nie mogli przekonać się, jak miała ta nowa formuła poezji wyglądać, gdyż nuta człowiecza okazała się rzeczywiście jego ostatnim tomem. Czechowicz zamilkł na wieki 9 IX 1939 w Lublinie, hitlerowska „bombą trafiony w stallach"22.

Wojna więc faktycznie zakończyła prawdziwy lub pozorny spór środowiska Skamandra $z$ awangardzistami, ale nie zakończyła sporu o kształt społeczeństwa,

J. Cze ch ow ic z, list do Redakcji „Kamy”, z 11 XII 1935. W: Listy, s. 311.

H. Blo om, Lęk przed wptywem. Teoria poezji. Przeł. A. Bielik-Robs on, M. Szuster. Kraków 2002, s. 132.

J. Cze ch ow ic z, list do K. A. Jaworskiego, z 12 XII 1935. W: Listy, s. 312-313.

J. Ś pi e wa k, Rozmowa z Józefem Czechowiczem. W: C z e c h ow i c z, Szkice literackie, s. 320.

J. Czech owicz, żal. W: Wybór poezji. Oprac. T. Kłak. Wyd. 2, uzup. Wrocław 1985, s. 142. BN I 199. 
w którym żyjemy. Argumentacja w dyskusji zaś dwóch adwersarzy związanych z tymi ugrupowaniami, pierwotnie mająca charakter czysto literacki, każe jeszcze raz zastanowić się, czy tak często przywoływana za wzór epoka Dwudziestolecia międzywojennego rzeczywiście dała naszej kulturze wyłącznie - najwyższej próby - merytoryczne polemiki, z których dzisiejsi adepci pióra winni brać przykład.

\author{
Abstract \\ MARCIN CAŁBECKI University of Gdańsk \\ SKAMANDER AND AVANT-GARDE ON THE FIRM GROUND ON KAROL WIKTOR \\ ZAWODZIŃSKI AND JÓZEF CZECHOWICZ'S ARGUMENT
}

The article is an account of a vigorous polemic between two important representatives of the Inter-war literary life, namely Karol Wiktor Zawodziński and Józef Czechowicz. It took place in the papers in the year 1935. On the surface, it referred to the issues connected with poetic criticism, but in consequence it led to personal accusations and almost ended with a duel. What remains in the background is the revealing of Czechowicz's homosexuality which in the 1930s meant infamy and became the source of his grave personal problems. The article also allows to reconsider the picture of Polish Inter-War literary life. As it transpires, the representatives of the epoch's elites were familiar with prejudice, disrelish and simple meanness. 